\title{
New mannose-specific lectins from garlic ( Allium sativum) and ramsons (Allium ursinum) bulbs *
}

\author{
Hanae Kaku ${ }^{a}$, Irwin J. Goldstein ${ }^{a}$, Els J.M. Van Damme ${ }^{\text {b }}$ \\ and Willy J. Peumans ${ }^{b}$ \\ a Department of Biological Chenistry, University of Michigan, Ann Arbor, Michigan 48109 (USA) \\ ${ }^{b}$ Laboratorium voor Phytopathologie en Plantenbescherming, Katholieke Universiteit Leuven, \\ Willern de Croylaan 42, B-3001 Leuven (Heverlee) (Belgium)
}

(Received June 3rd, 1991; accepted in revised form October 15th, 1991)

\begin{abstract}
Two new mannose-binding lectins were isolated from garlic (Allium sativum, ASA) and ramsons (Allium ursinum, AUA) bulbs, of the family Alliaceae, by affinity chromatography on immobilized mannose. The carbohydrate-binding specificity of these two lectins was studied by quantitative precipitation and hapten-inhibition assay. ASA reacted strongly with a synthetic linear $(1 \rightarrow 3)-\alpha-D-m a n n a n$ and $S$. cerevisiae mannan, weakly with a synthetic $(1 \rightarrow 6)-\alpha-\mathrm{D}-$ mannan, and failed to precipitate with galactomannans from $T$. gropengiesseri and $T$. lactis-condensi, a linear mannopentaose, and murine IgM. On the other hand, AUA gave a strong reaction of precipitation with murine IgM, and good reactions with $S$. cerevisiae mannan and both synthetic linear mannans, suggesting that the two lectins have somewhat different binding specificities for $\alpha$-D-mannosyl units. Of the saccharides tested as inhibitors of precipitation, those with $\alpha$-(1 $\rightarrow 3)$-linked mannosyl units were the best inhibitors of ASA, the $\alpha-(1 \rightarrow 2)$-, $\alpha$-(1 $\rightarrow 4)$-, and $\alpha$-(1 $\rightarrow 6)$-linked mannobioses and biosides having less than one eighth the affinity of the $\alpha-(1 \rightarrow 3)$-linked compounds. The $N$-terminal amino acid sequence of ASA exhibits $79 \%$ homology with that of AUA, and moderately high homology (53\%) with that of snowdrop bulb lectin, also an $\alpha$-D-mannosyl-binding lectin.
\end{abstract}

\section{INTRODUCTION}

Recently, we characterized the detailed carbohydrate-binding specificity of a new class of mannose-binding lectins isolated from snowdrop, daffodil, and amaryllis bulbs of the family Amaryllidaceae. These lectins possess high specificity for D-mannose, but differ somewhat from each other in their interaction with mannooligosaccharides $^{1-5}$.

Correspondence to: Professor I.J. Goldstein, Department of Biological Chemistry, University of Michigan, Ann Arbor, MI 48109, USA.

* This research was supported by NIH Grant GM 29470, F.G.W.O. grant 2005989 N, and grants of the National Fund for Scientific Research (Belgium). W.P. is Research Director and E.V.D. Research Assistant of this fund. 
In the present paper, we describe the sugar-binding specificity of two ncw mannose-specific lectins from garlic (ASA) and ramsons (AUA) bulbs. These plants belong to the Alliaceae family, which is of the same order, Liliales, as the family Amaryllidaceae ${ }^{6}$. We also compare the sugar-binding specificity of ASA and AUA with the three Amaryllidaceae lectins.

\section{RESULTS AND DISCUSSION}

The bulb lectin from garlic (Allium sativum, ASA) reacted strongly with a synthetic linear $(1 \rightarrow 3)$ - $\alpha$-D-mannan, moderately with a mannan from $S$. cerevisiae, and only slightly with a synthetic linear $(1 \rightarrow 6)$ - $\alpha$-D-mannan (Fig. 1). On the other hand, ASA failed to react with $P$. pastoris mannan, $T$. gropengiesseri and $T$. lactis-condensi galactomannans, Man-BSA conjugate, linear mannopentaose, synthetic linear ( $1 \rightarrow 3$ )- $\alpha$-D-glucan, bovine IgG, and rat and murine IgM (Fig. 1).

Conversely, the bulb lectin from ramsons (Allium ursinum, AUA) gave a pronounced precipitation reaction with murine IgM; this lectin also reacted well with the synthetic linear $(1 \rightarrow 3)$ - and $(1 \rightarrow 6)$ - $\alpha$-D-mannans and the $S$. cerevisiae mannan (Fig. 2), but only slightly with the galactomannan from T. lactis-condensi. However AUA did not react with the Man-BSA conjugate, C. lipolytica galactomannan, glycogen, dextran, pullulan, and bovine IgG. These observations suggest that the binding specificity of AUA is quite different from that of ASA, especially in its interaction with murine IgM. In this regard we have already studied the interaction of murine IgM with the mannose-binding bulb lectins from snowdrop (GNA), daffodil (NPA), and amaryllis (HHA). ASA is most similar to the snowdrop bulb lectin (GNA) ${ }^{1}$, with the exception that GNA gave a good precipitation reaction with the synthetic linear $(1 \rightarrow 6)$ - $\alpha$-D-mannan but interacted only slightly in a precipitation assay with murine IgM despite its ability, in its immobilized form,

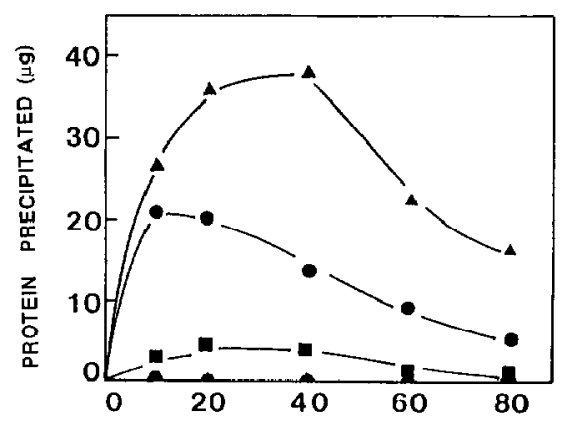

POLYSACCHARIDES OR MURINE IgM ADDED $(\mu \mathrm{g})$

Fig. 1. Quantitative precipitation of mannans by ASA. Each tube contained $30 \mu \mathrm{g}$ of ASA. Symbols: $\Delta$, synthetic linear $(1 \rightarrow 3)$ - $\alpha$-mannan; $\bullet, S$. cerevisiae mannan; $\mathbf{\square}$, synthetic linear $(1 \rightarrow 6)$ - $\alpha$-mannan; $\bullet$, murine IgM. ASA did not form precipitates with Man-BSA conjugate, $P$. pastoris mannan, $T$. gropengiesseri galactomannan, mannopentaose, $(1 \rightarrow 3)$ - $\alpha$-glucan, and rat and bovine IgG. 


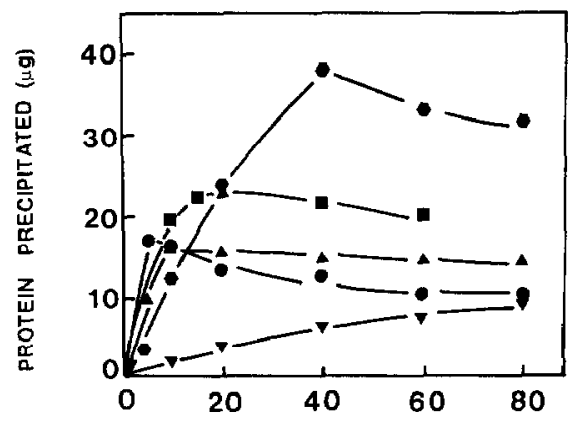

POLYSACCHARIDES OR MURINE IgM ADDED (ug)

Fig. 2. Quantitative precipitation of mannans and galactomannan by AUA. Each tube contained $20 \mu \mathrm{g}$ of AUA. Symbols: - , murine lgM; $\square$, synthetic linear $(1 \rightarrow 6)$ - $\alpha$-mannan; $\wedge$, synthetic linear $(1 \rightarrow 3)-\alpha$ mannan; •, S. cerevisiae mannan; $\mathbf{\nabla}, T$. lactis-condensi galactomannan. AUA did not react with Man-BSA conjugate, $C$. lipolytica galactomannan, glycogen, dextran, pullulan, or bovine IgG.

to bind murine $\operatorname{IgM}^{7}$. On the other hand, AUA is closely similar to the HHA lectin ${ }^{3}$ in its carbohydrate-binding activity.

Of the monosaccharides tested as inhibitors of ASA-mannan precipitation, D-mannose had a higher affinity for ASA than methyl $\alpha$ - or $\beta$-D-glucoside or

\section{TABLE I}

Inhibition by saccharides of mannan precipitation by ASA and AUA

\begin{tabular}{|c|c|c|c|c|}
\hline \multirow{3}{*}{$\begin{array}{l}\text { Sugar } \\
\text { D-Man }\end{array}$} & \multicolumn{4}{|c|}{ Concentration, $\mathrm{mM}$ (degree of inhibition, \%) } \\
\hline & \multicolumn{2}{|l|}{ ASA } & \multicolumn{2}{|c|}{ AUA } \\
\hline & 40.5 & $(50)$ & 72 & (50) \\
\hline$\alpha$-D-Man $p$-OMe & 27 & $(50)$ & 56 & $(50)$ \\
\hline$\beta$-D-Man $p$-OMe & 80 & $(0)$ & & \\
\hline$\alpha-\mathrm{D}-\mathrm{Man} p-\mathrm{O}-p-\mathrm{NP}{ }^{a}$ & 10 & (33) & & \\
\hline$\beta$-D-Man $p$-O- $p$-NP & 10 & $(0)$ & & \\
\hline 2-Deoxy-D-Man ${ }^{b}$ & 150 & (15) & & \\
\hline 3-Deoxy-D-Man ${ }^{b}$ & 70 & (50) & & \\
\hline 6-Deoxy-D-Man ${ }^{c}$ & 100 & (34) & & \\
\hline$\alpha-\mathrm{D}-\mathrm{Glc} p$-OMe & 100 & (13) & & \\
\hline$\beta$-D-Glc $p$-OMe & 100 & (9) & & \\
\hline$\alpha$-D-Glc $p$ NAc-OMe & 100 & (22) & & \\
\hline $\operatorname{Man} \alpha 1-2 \operatorname{Man}$ & 20 & (38) & 20 & (33) \\
\hline $\operatorname{Man} \alpha 1-3 \operatorname{Man}$ & 3.5 & $(50)$ & 10 & (30) \\
\hline $\operatorname{Man} \alpha 1-3 \operatorname{Man} \alpha-\mathrm{OMe}$ & 3.4 & (50) & 7 & (45) \\
\hline $\operatorname{Man} \alpha 1-3 \operatorname{Man} \alpha-O-$ allyl & 3.5 & $(50)$ & 10 & (31) \\
\hline $\operatorname{Man} \alpha 1-4 \operatorname{Man} \alpha-\mathrm{OMe}$ & 20 & (30) & 20 & $(0)$ \\
\hline $\operatorname{Man} \alpha 1-6 \mathrm{Man} \alpha-\mathrm{OMe}$ & 20 & (14) & 14 & $(50)$ \\
\hline $\operatorname{Man} \alpha 1-6 \mathrm{Glc}$ & 10 & $(0)$ & & \\
\hline $\operatorname{Man} \alpha 1-6 \operatorname{Man} \alpha 1-6 \mathrm{Man}$ & & & 10.4 & $(50)$ \\
\hline $\operatorname{Man}_{4}$ Man-ol & 3 & (30) & & \\
\hline $\begin{array}{l}\operatorname{Man} \alpha 1-6 \\
\operatorname{Man} \alpha 1-3\end{array}$ & 8 & (28) & 6.4 & $(50)$ \\
\hline
\end{tabular}


methyl 2-acetamido-2-deoxy- $\alpha$-D-glucoside (9\% to $22 \%$ inhibition at $100 \mathrm{mM}$ Table I). This lectin prefers the $\alpha$ configuration: for $\alpha$-D-Man $p$-OMe a concentration 27 $\mathrm{mM}$ was required for $50 \%$ inhibition of the ASA system, whereas $\beta$-D-Man $p$-OMe at $80 \mathrm{mM}$ gave no inhibition. Deoxy derivatives (2-deoxy-D-Man, 3-deoxy-D-Man, and 6-deoxy-D-Man, see Table I) were also much less active than D-mannose.

Of the oligosaccharides examined, $(1 \rightarrow 3)$ - $\alpha$-mannobiose and its derivatives (Man $\alpha 1-3 \operatorname{Man} \alpha$-OMe and Man $\alpha 1-3 \operatorname{Man} \alpha$-O-allyl) were the best inhibitors of the ASA-mannan system, concentrations of $3.5 \mathrm{mM}$ being required for $50 \%$ inhibition. It appears that the $\alpha-(1 \rightarrow 3)$ linkage is most complementary to the sugar-binding site of ASA [ $(1 \rightarrow 2)-,(1 \rightarrow 3)$-, and $(1 \rightarrow 6)$ - $\alpha$-mannobiuse and their glycosides were poorer inhibitors]. Interestingly, mannotetraosylmannitol (Man $\alpha 1-3$ Man $\alpha 1$-3Man $\alpha 1-3 M a n \alpha 1-2 M a n-o l$, Man $_{4}$ Man-ol) was less active than $(1 \rightarrow 3)_{-} \alpha-$ mannobiose, suggesting that, in some manner, an extension of $\alpha$-(1 $\rightarrow 3)$-linked mannose units inhibits binding to ASA. Furthermore, maltose $[(1 \rightarrow 4)-\alpha-$ glucobiose $]$ and nigerose $[(1 \rightarrow 3)$ - $\alpha$-glucobiose $]$ were noninhibitors of the precipitation reaction. Interestingly, the branched mannotrisaccharide Man $\alpha 1-3$ (Man $\alpha 1-6$ ) Man $\alpha$-OMe was less inhibitory than methyl $(1 \rightarrow 3)-\alpha$ mannobioside. This observation indicates that the mannose residue attached at the C-6 position of the penultimate mannosyl unit may exert steric hindrance on ASA sugar-binding sites.

These observations indicate that the binding specificity of ASA differs from those of the three aforementioned mannose-binding lectins (GNA, NPA, and HHA) in its low affinity for methyl $(1 \rightarrow 6)$ - $\alpha$-mannobioside (Table II). It appears that the sugar-binding sites of ASA are complementary to $\alpha$-( $1 \rightarrow 3)$-linked mannosyl units. Thus, ASA appears to be more closely related in its carbohydrate-bind-

\section{TABLE II}

Inhibition by various sugars of five mannan-specific lectin-yeast mannan precipitation systems

\begin{tabular}{|c|c|c|c|c|c|}
\hline \multirow[t]{2}{*}{ Sugar } & \multicolumn{5}{|c|}{ Relative inhibitory potency } \\
\hline & ASA & AUA & $\mathrm{GNA}^{a}$ & $\mathrm{NPA}^{b}$ & $\mathrm{HHA}^{b}$ \\
\hline D-Man & 1.0 & 1.0 & 1.0 & 1.0 & 1.0 \\
\hline$\alpha$-D-Man $p$-OMe & 1.5 & 1.3 & 1.6 & 1.2 & 1.5 \\
\hline$\beta$-D-Man $p$-OMe & $\ll 0.4$ & & 0.3 & 0.2 & 0.5 \\
\hline $\operatorname{Man} \alpha 1-2 \operatorname{Man}$ & $<1.4$ & $<3.6$ & 2.1 & 3.3 & 3.2 \\
\hline $\operatorname{Man} \alpha 1-3 \operatorname{Man}$ & 11.5 & $<7.2$ & 12.1 & 2.8 & 5.9 \\
\hline $\operatorname{Man} \alpha 1-3 \mathrm{Man} \alpha$-OMe & 11.9 & 10 & 14.2 & 3.1 & 10.5 \\
\hline $\operatorname{Man} \alpha 1-3 \operatorname{Man} \alpha-O-$ allyl & 11.5 & $<7.2$ & & & \\
\hline $\operatorname{Man} \alpha 1-4 \operatorname{Man} \alpha-\mathrm{OMe}$ & $<1.4$ & $\ll 3.2$ & 1.9 & $<0.7$ & $<2.0$ \\
\hline $\operatorname{Man} \alpha 1-6 \operatorname{Man} \alpha-\mathrm{OMe}$ & $\ll 1.4$ & 5.1 & 4.3 & 5.1 & 8.3 \\
\hline $\begin{array}{l}\operatorname{Man} \alpha 1-6 \operatorname{Man} \alpha 1-6 \operatorname{Man} \\
\operatorname{Man} \alpha 1-6\end{array}$ & & 6.9 & 1.9 & 0.7 & 20.0 \\
\hline $\operatorname{Man} \alpha 1-3-\operatorname{Man} \alpha-\mathrm{OMe}$ & $\ll 3.6$ & 11.3 & 28.3 & 3.8 & 13.8 \\
\hline
\end{tabular}

${ }^{a}$ Data from Shibuya et al. ${ }^{1}$ using the GNA-H. capsulata mannan precipitation system. ${ }^{b}$ Data from Kaku et al. ${ }^{3}$ using the NPA- and HHA-P. pastoris mannan precipitation systems. 


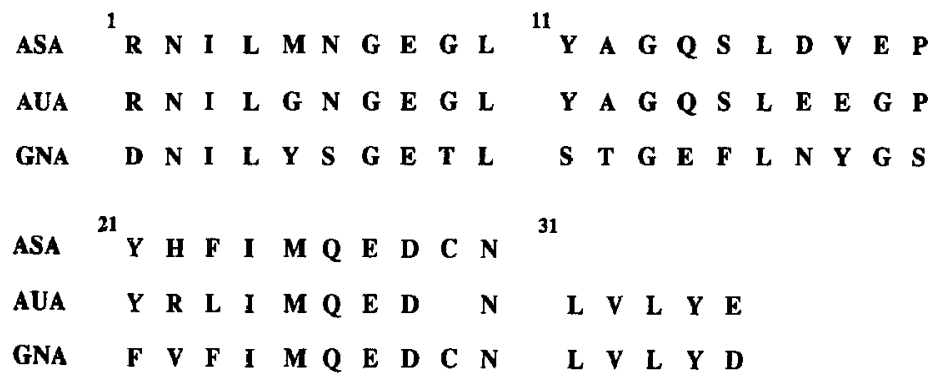

Fig. 3. $N$-Terminal amino acid sequences of ASA, AUA, and GNA, described by the standard one-letter code ${ }^{15}$.

ing specificity to GNA, with the cxception that $(1 \rightarrow 3)-\alpha$-mannobiose or bioside is only a three times better inhibitor than methyl $(1 \rightarrow 6)$ - $\alpha$-mannobioside for the GNA precipitation system, and GNA has a very strong affinity for the branched mannotrioside Man $\alpha 1-3(\operatorname{Man} \alpha 1-6) \operatorname{Man} \alpha$-OMe.

On the other hand, Man $\alpha 1-3(\operatorname{Man} \alpha 1-6) \operatorname{Man} \alpha-O M e$ was the best inhibitor of the AUA-mannan precipitation system. This branched mannotrisaccharide was 1.6 times better than the $\alpha$-( $1 \rightarrow 6)$-linked mannobioside and exhibited inhibitory potency similar to that of methyl $(1 \rightarrow 3)$ - $\alpha$-mannobioside. Thus, the sugar-binding specificity of AUA is similar to that of HHA (Table II). Moreover, the major structure of the high-mannose type oligosaccharide unit of murine IgM is $\mathrm{Man}_{6}$ GlcNAc (ref. 8). We already noted that $\mathrm{Man}_{5} \mathrm{GlcNAc}_{2}$ Asn (GP-V) bound to an HHA-Sepharose column and $\mathrm{Man}_{6} \mathrm{GlcNAc}_{2}$ Asn showed even greater affinity for this column. This observation also indicates that AUA should react with murine IgM.

It has already been noted that the bulb lectins from the Alliaceae and Amaryllidaceae are related serologically ${ }^{6}$ and exhibit high affinity for D-mannose. The amino acid compositions of ASA and AUA are very similar ${ }^{6}$, and the $N$-terminal amino acid sequences of ASA and AUA, presented in Fig. 3, indicate 79\% homology between these two lectins. Furthermore, the amino acid sequence of ASA shows a rather high homology (53\%) with that of GNA.

In summary, new mannose-binding lectins have been isolated from garlic and ramsons bulbs. These two lectins exhibit subtle differences from each other in their affinity for $\alpha$-D-mannosyl units, and also from the three mannose-binding bulb lectins described previously (Table II). We believe these fine differences in sugar-binding specificity should make these bulb lectins useful tools for investigating saccharides and glycoconjugates containing $\alpha$-D-mannosyl units.

\section{EXPERIMENTAL}

The garlic and ramsons lectins (ASA and AUA, respectively) were isolated from extracts of their bulbs by affinity chromatography on immobilized mannose as previously reported ${ }^{6}$. 
Saccharides and glycoproteins. - Man $\alpha 1-3 \mathrm{Man}$ and Man $\alpha 1-3 \mathrm{Man} \alpha-\mathrm{O}$-allyl were the gifts of Dr. K.L. Matta of the Roswell Park Memorial Institute, Buffalo, NY. Man $\alpha 1-3 \operatorname{Man} \alpha$-OMe, Man $\alpha 1-4 \operatorname{Man} \alpha$-OMe, and Man $\alpha 1-6$ Man $\alpha$-OMe were purchased from the Sigma Chemical Co., St. Louis, MO. The synthetic phosphorylated mannopentaose (P-Man $\alpha 1-3 \operatorname{Man} \alpha 1-3 \operatorname{Man} \alpha 1-3 \operatorname{Man} \alpha 1-2 \mathrm{Man}$ ) was the generous gift of Dr. Y.C. Lee, The Johns Hopkins University, Baltimore, MD. Mannopentaose was prepared from phosphorylated mannopentaose by treatment with alkaline phosphatase (Type XXX from unweaned-calf intestinal mucosa, Sigma), and $\operatorname{Man}_{4}$ Man-ol was prepared from mannopentaose by reduction with sodium borohydride as previously described ${ }^{5}$.

Murine IgM and IgG were obtained from Dr. J.L. Claflin of the University of Michigan, and bovine and rat IgG were purchased from the Sigma Chemical Co. Yeast mannans and galactomannans from various strains were supplied by Dr. P.A.J. Gorin of the Universidade Federal do Parana, Curitiba, Brazil. A synthetic linear $(1 \rightarrow 6)$ - $\alpha$-D-mannan, a $(1 \rightarrow 3)$ - $\alpha$-D-mannan (dp 30) and ( $\rightarrow 3$ )- $\alpha$-D-glucan were generously provided by Dr. C. Schuerch, State University of New York at Syracuse ${ }^{9-11}$. Other monosaccharides and their derivatives were commercially available.

Quantitative precipitation and precipitation-inhibition assays. - Quantitative precipitation assays were carried out by a micro technique ${ }^{12}$. ASA ( $30 \mu \mathrm{g}$ or AUA $(20 \mu \mathrm{g})$ was mixed with varying amounts of polysaccharides, manno-oligosaccharides, or immunoglobulins in a total volume of 110 or $150 \mu \mathrm{L}$ (respectively) of $10 \mathrm{mM}$ phosphate buffer ( $\mathrm{pH} 7.2$ ) containing $0.1 \mathrm{mM} \mathrm{CaCl}_{2}, 0.04 \% \mathrm{NaN}_{3}$, and 150 $\mathrm{mM} \mathrm{NaCl}$. After incubation at $37^{\circ}$ for $1 \mathrm{~h}$, the mixtures were kept at $4^{\circ}$ for 2 days, and centrifuged at $8800 \mathrm{~g}$ for $10 \mathrm{~min}$. Protein in the precipitates was determined by the method of Lowry et al. ${ }^{13}$, using bovine serum albumin as standard.

Sugar inhibition of the precipitation reactions was carried out by adding increasing amounts of sugar or sugar derivative to precipitation systems containing lectin and $S$. cerevisiae mannan. The precipitated protein was determined by the procedure of Lowry et al. ${ }^{13}$

Amino acid sequencing. - Amino acid sequencing was performed by Drs. S.F. Perini and P. Andrews of the University of Michigan Biomedical Core Facility ${ }^{14}$.

\section{REFERENCES}

1 N. Shibuya, I.J. Goldstein, E.J.M. Van Damme, and W.J. Peumans, J. Biol. Chem., 263 (1988) $728-734$.

2 H. Kaku and I.J. Goldstein, Methods Enzymol., 179 (1989) 327-331.

3 H. Kaku, E.J.M. Van Damme, W.J. Peumans, and I.J. Goldstein, Arch. Biochem. Biophys., 279 (1990) 298-304.

4 H. Kaku, I.J. Goldstein and S. Oscarson, Carbohydr. Res., 213 (1991) 109-116.

5 H. Kaku and I.J. Goldstein, Carbohydr. Res., 229 (1992) 337-346.

6 E.J.M. Van Damme, I.J. Goldstein, and W.J. Peumans, Phytochemistry, 30 (1991) 309-514.

7 N. Shibuya, J.E. Berry, and I.J. Goldstein, Arch. Biochem. Biophys., 267 (1988) 676-680. 
8 R. Brenckle and R. Kornfeld, Arch. Biochem. Biophys., 201 (1980) 160-173.

9 J.W.-P. Lin and C. Schuerch, J. Polym. Sci., Part A-1, 10 (1972) 2045-2060.

10 F. Kong and C. Schuerch, Macromolecules, 17 (1984) 983-989.

11 F.J. Good, Jr. and C. Schuerch, Macromolecules, 18 (1985) 595-599.

12 L.L. So and I.J. Goldstein, J. Biol. Chem., 242 (1967) 1617-1622.

13 O.H. Lowry, N.J. Rosebrough, A.L. Farr, and R.J. Randall, J. Biol. Chem., 193 (1951) $265-275$.

14 D.R. Koo, E.T. Morgan, G.E. Tarr, and M.J. Coon, J. Biol. Chcm., 257 (1982) 8472-8480.

15 IUPAC-IUB Joint Commission on Biochemical Nomenclature, J. Biol. Chem., 260 (1985) $14-42$. 